\title{
26. REMARKS ON CRETACEOUS-TERTIARY ICHTHYOLITH STRATIGRAPHY IN THE ATLANTIC, OCEAN DRILLING PROGRAM LEG 103 ${ }^{1}$
}

\author{
P. S. Doyle, Scripps Institution of Oceanography, University of California, San Diego, La Jolla, California
}

\begin{abstract}
The pattern of ichthyolith distribution established in sequences with stratigraphies based on calcareous or siliceous microfossils is used to provide age correlations for three deep-sea pelagic clay intervals that lack the better known microfossils. At Site 637, approximately $25 \mathrm{~m}$ of brown clay in Cores 103-637A-21R through 103-637A-23R underlies upper Miocene sediments and is of Paleocene to early Eocene age. At Site 639, $1.7 \mathrm{~m}$ of brown clay in Core 103-639C-2R is Eocene to Oligocene. At Site $640,3.5 \mathrm{~m}$ of clay in Cores 103-640A-1R and 103-640A-2R contains a Cretaceous to Paleocene sequence, with the Cretaceous/Tertiary boundary between 84 and $103 \mathrm{~cm}$ in Section 103-640A-2R-1.
\end{abstract}

\section{INTRODUCTION}

Four sections of pelagic clays lacking siliceous or calcareous microfossils were recovered from the Galicia margin during Ocean Drilling Program (ODP) Leg 103 (Fig. 1). Ichthyoliths (fish skeletal fragments of calcium phosphate) are present throughout these clays, and agglutinated foraminifers occur less commonly (Moullade et al., this volume). Three of the intervals have sufficient ichthyoliths for biostratigraphic age interpretations at about the subepoch level, as follows:

Hole 637A: $42^{\circ} 05.3^{\prime} \mathrm{N}, 12^{\circ} 51.8^{\prime} \mathrm{E}$; water depth $5307 \mathrm{~m}$ Hole 639C: $42^{\circ} 08.6^{\prime} \mathrm{N}, 12^{\circ} 15.1^{\prime} \mathrm{E}$; water depth $4756 \mathrm{~m}$ Hole $640 \mathrm{~A}$ : $42^{\circ} 00.7^{\prime} \mathrm{N}, 12^{\circ} 27.8^{\prime} \mathrm{E}$; water depth $5196 \mathrm{~m}$

Approximately $40 \mathrm{~m}$ of brown clay that also contains assemblages of long-ranging Late Cretaceous age agglutinated foraminifers occurs at Site 641 (Samples 103-641A-3X-1 through 103-641A-6X-7). However, because no ichthyolith stratigraphy has been developed for the Cretaceous, the biostratigraphic resolution for this section cannot be improved.

To increase the reliability of ichthyolith stratigraphy, I also report in this chapter on ichthyoliths in samples from the following Atlantic Deep Sea Drilling Project (DSDP) sites that are correlated with the stratigraphies of other microfossil groups:

Site 118: $45^{\circ} 02.6^{\prime} \mathrm{N}, 9^{\circ} 00.6^{\prime} \mathrm{E}$; water depth $4901 \mathrm{~m}$

Site 119: $45^{\circ} 01.9^{\prime} \mathrm{N}, 7^{\circ} 58.5^{\prime} \mathrm{E}$; water depth $4447 \mathrm{~m}$

Site 361 : $35^{\circ} 03.9^{\prime} \mathrm{S}, 15^{\circ} 26.9^{\prime} \mathrm{E}$; water depth $4548 \mathrm{~m}$

These samples, which have age assignments based on the nannofossil zonation of Bukry (Okada and Bukry, 1980), form a minimal Cretaceous-Tertiary reference framework for the Paleogene of this region and supplement the global summary of ichthyolith occurrences in samples with ages based on other fossil groups (table 3 in Gottfried et al., 1984b).

Ichthyolith age assignments for the ODP Leg 103 intervals are presented in Table 1 . Age assignments were made by comparing the patterns of occurrences of taxa in two reference columns-the regional composite reported here in Table 2 and the summary given in Gottfried et al. (1984b) - with those in the Leg 103 samples. Additional information on the relative ranges of taxa is taken from giant piston core 3 (GPC-3; Doyle and

\footnotetext{
${ }^{1}$ Boillot, G., Winterer, E. L., et al., 1988. Proc. ODP, Sci. Results, 103: College Station, TX (Ocean Drilling Program).
}

Riedel 1979b; Corliss et al., 1982). The GPC-3 recovered brown clay that probably represents a steady record of Cretaceous through Recent sedimentation in the central North Pacific gyre (Doyle, 1982; Kyte and Watson, 1986). Because it contains relatively large assemblages of ichthyoliths (200-3000 triangular forms/sample), GPC-3 provides the most complete register of ichthyolith events available and has been used as a reference section for several ichthyolith studies that identify new, stratigraphically useful taxa (Gottfried et al., 1984a; Doyle and Riedel, 1985b; Tway et al., 1985).

The tabulations of taxa in Tables 1 and 2 indicate the sparseness of specimens in samples of the size normally obtained through ODP. The low numbers and patchiness of occurrences hamper refining the stratigraphic resolution, which depends, in part, on an established sequence of first and last appearances. However, a general pattern of ichthyolith subtypes through time is sufficiently well known to permit age assignments at about the subepoch level.

The taxa in Tables 1 and 2 are organized by their earliest appearance in the previously discussed reference samples. Although the ranges of the taxa are not generally coherent, particularly in the Site 119 Oligocene and Miocene section where the sample size and numbers of ichthyoliths are small, the dated samples of Table 2 do not contradict the established order of first appearances in the summary table of Gottfried et al. (1984b). The Leg 103 brown clay sections discussed here also exhibit this established order of first appearances (Table 1).

The taxa searched for in this study are listed by their colloquial names with taxonomic references in the "List of Taxa." I selected 70 of the most biostratigraphically useful taxa from the various time divisions for age interpretations. The main selection criteria were presence in the samples, ease of shape recognition, clear taxonomic concepts, the frequency with which the taxa occur in past studies, and sufficient taxa to correlate the sequences.

The samples are of two different sizes. Samples that lack an entry for dry weight in Table 2 are from a previous ichthyolith study (Doyle et al., 1974) and are $20-30 \mathrm{~cm}^{3}$. The rest of the samples, from Leg 103, are $50 \mathrm{~cm}^{3}$. Preparation of the samples and counting of the ichthyoliths followed the procedures described by Edgerton et al. (1977) with one addition, that preparations were made of the $44-64-\mu \mathrm{m}$ sieved residue also. These smaller ichthyoliths have been included in recent ichthyolith investigations, but tabulations for this size fraction are not included in this report, partly because of insufficient time to search through the subsamples and partly because this finer fraction was not included in the tabulations of the summarized 


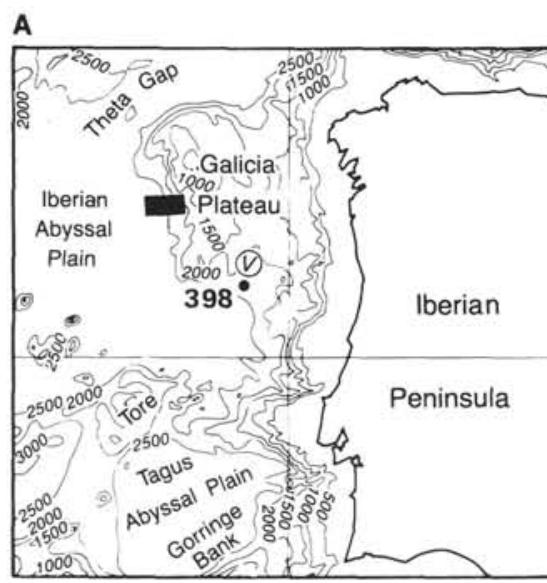

B

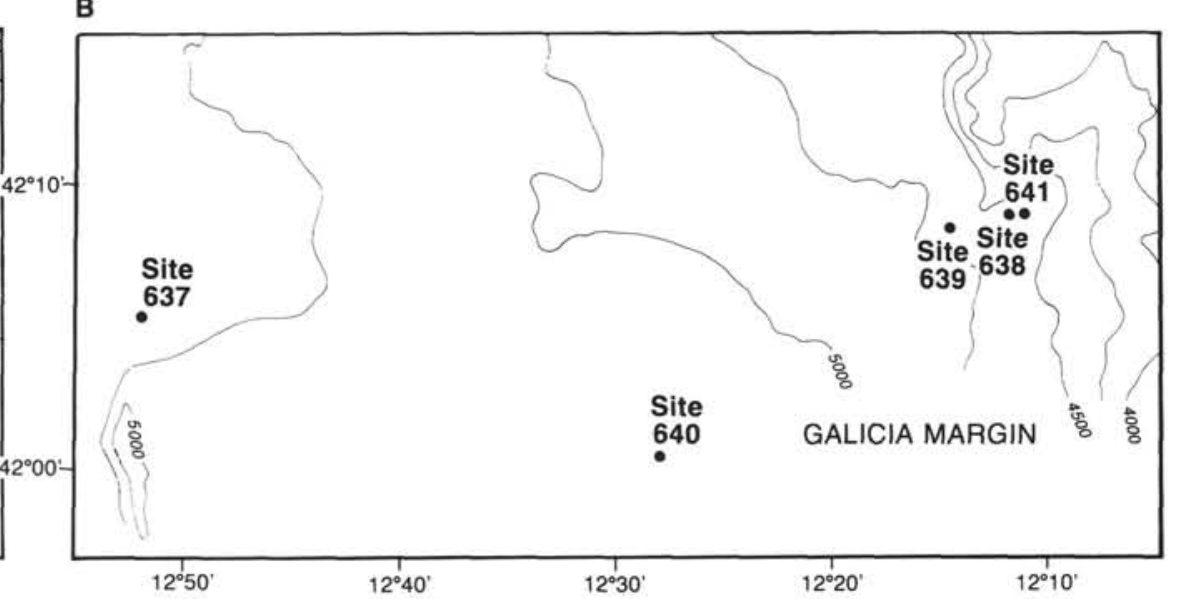

Figure 1. Location of Ocean Drilling Program Leg 103 sites. A. Location map of Galicia margin region northwest of the Iberian Peninsula. B. Bathymetric map showing location of sites drilled. Modified from Sea Beam map; contour interval $250 \mathrm{~m}$.

dated reference column for the major oceans (Gottfried et al., $1984 \mathrm{~b})$ or investigated in the preceding study of samples from Site 119 (Table 2).

\section{BIOSTRATIGRAPHIC RESULTS AND SPECIES OCCURRENCES}

The Leg 103 "barren" brown clay intervals are of Cretaceous through Paleogene age. Clays lacking siliceous or calcareous fossils were widely deposited throughout the Atlantic during this time period. Ichthyolith correlations for otherwise unfossiliferous intervals of similar ages have been reported from North Atlantic DSDP Sites 105, 137, 141, 367, 382, and 385 (Kaneps et al., 1981; Gottfried et al., 1984b) and South Atlantic DSDP Sites 361 and 365 (Doyle et al., 1978).

Tables 1 and 2 show the number of specimens of each taxon present, the total number of tooth-shaped ichthyoliths, and the number per gram of dry sediment. In the brown clay sections of Table 1, the numbers of triangular ichthyoliths per gram dry weight range from about 1 to 5 , with only a Miocene sample from Hole 637A and an Eocene sample from Hole $639 \mathrm{C}$ containing significantly more. The number of ichthyoliths in the samples with calcareous microfossils show a similar range in Table 2 . As noted in the footnote to the table, the samples of late Paleocene age from DSDP Sites 118 and 119 either contain only a few brown fragments of biogenic apatite or are barren. Samples of approximately the same age from Site 361 in the South Atlantic have good ichthyolith assemblages and are included in Table 2 to provide some reference samples for the time period. The ichthyolith assemblages reported from DSDP Site 361 (Doyle et al., 1978) have been retabulated to include some of the taxa that have been described since then (Gottfried et al., 1984a; Tway et al., 1985; Doyle and Riedel, 1985b; Winfrey et al., 1987).

The bases for the age assignments of the Leg 103 brown clay intervals (Table 1) are discussed in the following.

\section{Site 637}

One hole (Hole 637A) was rotary drilled at this site. Two hundred and twelve meters of Tertiary sediments were continuously cored to basement, with an average recovery of about $30 \%$. Core 103-637A-1R through Sample 103-637A-15R-3, $3 \mathrm{~cm},(0$ $135 \mathrm{~m}$ below seafloor [mbsf]) consist of middle Pliocene to upper Pleistocene turbidites containing calcareous microfossils; Sample 103-637A-15R-3, $3 \mathrm{~cm}$, through Section 103-637A-20R-1 (135-181 mbsf) contain upper Miocene to middle Pliocene interbedded marl and calcareous turbidites with lower amounts of brown clay; Section 103-637A-20R-6 through Sample 103-637A23R-2, $135 \mathrm{~cm},(187-212 \mathrm{mbsf})$ are pelagic and hemipelagic brown and reddish clay. Foraminifers in the core-catcher samples from this last interval are thought to be displaced (see "Site 637" chapter; Shipboard Scientific Party, 1987). Nannofossils in Section 103-637A-20R-1 are of late Miocene age (CN9).

Ichthyoliths in the approximately $25 \mathrm{~m}$ of brown and reddish brown clay (Cores 103-637A-21R through 103-637A-23R) between the upper Neogene section and basement indicate that this interval is predominantly lower Paleogene. Only the ichthyoliths in the uppermost sample from Section 103-637A-20R-1 (180 mbsf) are Neogene. This sample is Miocene, based on the presence of Small triangle long striations, Long triangle short inline, and Stippled triangle. Forms typically found in the upper Miocene that are present in Pliocene samples at Site 639 (Table 1) are absent (Triangle double inline, Triangle irregular base, and Long triangle stepped margin). The absence of late Miocene and younger taxa and the presence of older forms not generally found in younger deposits (Triangle with triangular projection and Triangle notched corner) suggest an early or middle Miocene age, which is in disagreement with the evidence from calcareous microfossils for a late Miocene correlation. This conflict probably results from limited knowledge of the factors influencing ichthyolith distribution, a situation that should improve as the fish that produce specific skeletal elements are identified.

In Cores 103-637A-21R through 103-637A-23R, the first occurrences of the ichthyolith taxa indicate a lower Paleogene sequence that increases in age with depth (Table 1). Core 103$637 \mathrm{~A}-21 \mathrm{R}$ is probably lower Eocene because a few forms that first appear in this subepoch are present (Flexed triangle shallow inbase, Wide triangle straight inbase, and Narrow triangle straight inbase). Cores 103-637A-22R and 103-637A-23R are $\mathrm{Pa}-$ leocene on the basis of the presence of Short triangle bowed inline, a taxon so far found only in Paleocene assemblages.

The lowermost sample, from Section 103-637A-23R-2, is about $15 \mathrm{~cm}$ above basement and contains two described Cretaceous subtypes (Centrally striated triangle and Blunt triangle dendritic inline), as well as some undescribed Cretaceous forms mixed with early Tertiary age taxa (Short triangle bowed inline and Triangle radiating inline).

This lower Paleogene sequence represents an accumulation rate of about $1 \mathrm{~m} / \mathrm{m}$.y. This compares with $0.3 \mathrm{~m} / \mathrm{m}$.y. for the same time period in the North Pacific from GPC-3 recovery (Doyle and Riedel, 1979b). 


\section{Site 639}

The main objective at Site 639 was to collect data on the Mesozoic history of sedimentation and onset of Atlantic margin rifting. The site was selected because of the relatively thin layer of Cenozoic sediments. One deep hole was planned, but because of difficulties with hole instability, a total of six holes of varying depths was rotary drilled. A spotty record of Cenozoic sedimentation was recovered from several of the holes. Calcareous and siliceous microfossils in the cores suggest a record of Early Cretaceous deposition unconformably overlain by upper Miocene through Pleistocene sediments.

Two cores were recovered at Hole 639C. Core 103-639C-1R (78-90.8 mbsf) contains a nannofossil ooze and marl interval with foraminifers of early to middle Pliocene age foraminifers and Pliocene nannofossils. The ichthyolith assemblages do not contradict this age assignment, thus increasing the data base of Atlantic samples that have both ichthyoliths and age control provided by other microfossils.

In Core $103-639 \mathrm{C}-2 \mathrm{R}(90.8-100.4 \mathrm{mbsf})$, the upper $1.9 \mathrm{~m}$ is brown silty clay and lower $60 \mathrm{~cm}$ is dolomite. Ichthyoliths in Sample 103-639C-2R-1, 20-27 cm, are Oligocene on the basis of the presence of Triangle with high inline apex and Rectangular saw-toothed, subtypes that first appear in Oligocene assemblages. Other late Paleogene age taxa are present (Triangle notched corner and Rounded apex triangle), but Miocene taxa are absent. The other samples from this core section (Samples 103-639C-2R-1, 93-100 cm, and 103-639C-2R-1, 117-122 cm) are probably late early or middle Eocene age because Triangle notched corner is absent and both Triangle double flex and Broad triangle parallel inline are present. In the summary of reference samples published by Gottfried et al. (1984b), these three forms first appear together in the upper lower Eocene; the latter two subtypes range consistently through the rest of the Eocene, but Triangle notched corner does not appear again until the late Eocene, with a coherent range through early Miocene. Triangle notched corner is one of the more common forms for this time period in the northeastern Atlantic. In Sample 103-639C-2R-2, $23-28 \mathrm{~cm}$, evidence is sufficient only to suggest a late Paleocene or early Eocene age, although Eocene is more likely because none of the typical Paleocene forms is present.

\section{Site 640}

One hole (Hole 640A) was rotary drilled at this site. The first two cores were taken from 145.4-155.1 and 155.1-164.7 mbsf, respectively. Core $103-640 \mathrm{~A}-1 \mathrm{R}$ contains $1.5 \mathrm{~m}$ of brown clay, and $2 \mathrm{~m}$ of clay overlie Aptian-Barremian chalk in Core 103640A-2R. Siliceous and calcareous microfossils are lacking in the clay section, though agglutinated foraminifers are present.

Ichthyoliths in Core 103-640A-1R indicate a late Paleocene or possibly an early Eocene age. The Cretaceous/Tertiary boundary occurs in Section 103-640A-2R-1 between 84 and $103 \mathrm{~cm}$. The assemblages in the $0.5-\mathrm{m}$ interval above the boundary consist mostly of forms that first appeared during the Mesozoic, survived the terminal crisis, and continued well into the Tertiary. Fibrous triangle convex margins and Triangle complex transverse line are two of these taxa that have continued into presentday assemblages. Some of the described and undescribed ichthyoliths that continue through the Cretaceous/Tertiary boundary are illustrated in Plates 1-3.

The deepest sample in the first section (Sample 103-640A$2 \mathrm{R}-1,103-110 \mathrm{~cm}$ ) and the samples from Section 103-640A-2R-2 are Cretaceous. As noted above, Cretaceous ichthyolith stratigraphy is not sufficiently developed to detect the unconformity that evidently exists between the Cretaceous/Tertiary boundary and the Aptian chalk.

Several Cretaceous forms (Whorled triangle, Triangle square inline, and Centrally striated triangle) that appear in the overly- ing lower Paleocene samples indicate sediment mixing across the boundary. This is also apparent across the Cretaceous/Tertiary boundary in GPC-3. Whereas the extent of the mixing is not so clearly defined by the ichthyolith distribution, the iridium profile in GPC-3 shows sediment mixing to about $40 \mathrm{~cm}$ above the iridium boundary spike (Kyte and Watson, 1986).

\section{NOTES AND TAXONOMIC REFERENCES ON TAXA USED}

Of the approximately 160 described ichthyolith taxa, I searched for 102 in this study. These subtypes are listed in the following with reference to the original description and an additional reference to the current taxonomic concept where necessary. The descriptive scheme on which the subtypes are defined is a system of morphological descriptors suitable for computer storage and manipulation, summarized in Doyle and Riedel (1979a) and amended by Doyle and Riedel (1980, 1985b), Gottfried et al. (1984a), Tway et al. (1985), and Winfrey et al. (1987).

Subtypes used in this study for biostratigraphic interpretations are identified with a "plus" in front of the colloquial name in the taxa list, and the number of specimens for the taxon in the samples is shown in Tables 1 and 2. Occurrence data for subtypes present in these samples, but not included in the tables, follow the colloquial name entry. Specimens that are similar to described subtypes (indicated by $C$ in the tables) are also discussed. The more biostratigraphically significant examples of these forms are illustrated in Plate 4.

Cenozoic and Cretaceous ichthyoliths found in pelagic sediments are generally cosmopolitan in their distribution. At the level of discrimination permitted by the present set of morphological descriptors, few described ichthyoliths are geographically restricted. Of the following taxa looked for and not found, the majority are absent because the time period in which they are most abundant is not well represented in this sample set. Some of the taxa not found are relatively rare forms for which absence cannot be considered significant. Taxa that are present in the Pacific and the Western Atlantic, but are absent or very rare in the Eastern Atlantic and the Indian Ocean, include Large with numerous lines Doyle et al. (1974), Small dendritic many radiating lines Doyle et al. (1974), and Small dendritic few radiating lines Doyle et al. (1974).

The other subtypes looked for and not found are Asymmetrical peak depression Gottfried et al. (1984a), Flexed triangle shallow inbase $\geq 120$ Dunsworth et al. (1975), Large triangle saw-toothed margin Doyle et al. (1974), Long ellipse Gottfried et al. (1984a), Narrow straight triangle Doyle and Riedel (1985b), Narrow triangle ragged base Dunsworth et al. (1975), Ogee lanceolate Tway et al. (1985), Rectangular peaked projection Tway et al. (1985), Small triangle hooked margin Tway et al. (1985), Tall triangle low inline Ramsey et al. (1976), Three tall peaks Dunsworth et al. (1975), Triangle concave first margin Gottfried et al. (1984a), Triangle crenulate Doyle et al. (1974), Triangle many projections Winfrey et al. (1987), and Triangle trailing margin Ramsey et al. (1976).

\section{LIST OF TAXA}

+ Asymmetrical peak wide depression Doyle et al., 1974; Doyle and Riedel, 1979a.

+ Beveled triangle concave margins Doyle and Riedel, 1985b.

+ Beveled triangle high inline Doyle et al., 1978; Doyle and Riedel, 1979a. + Beveled triangle mid inline Doyle et al., 1978; Doyle and Riedel, 1979a. Blunt triangle dendritic inline Doyle et al., 1978; Doyle and Riedel, 1985 a, p. 982. One specimen is apparently reworked into Paleocene Sample 103-637A-23R-2, 111-118 cm, and one specimen in Cretaceous Sample 103-640A-2R-1, 103-110 cm.

Blunt triangle long margins Winfrey et al., 1987. This relatively common subtype was originally described from Mesozoic assemblages 
Table 1. Distribution of selected, stratigraphically useful taxa in brown clay intervals from Ocean Drilling Program Leg 103. Taxa are arranged in order of their earliest appearance, as explained in the text. Numbers in the body of the table are the actual numbers of specimens found in the samples. ? = broken specimens similar to the subtype; $\mathrm{C}=$ similar-appearing specimens. These forms are discussed under the colloquial name of the taxon in the "List of Taxa."

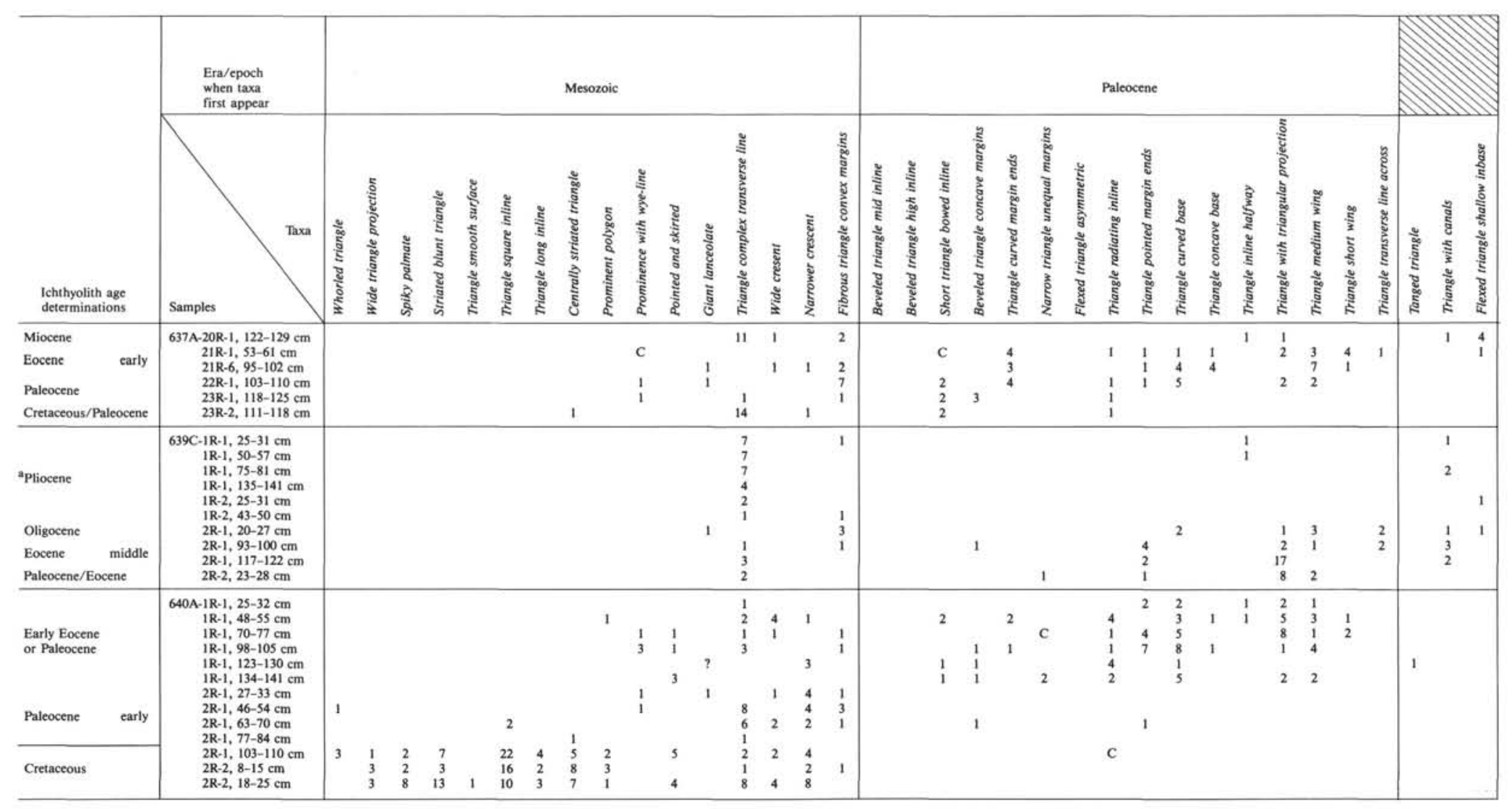

"Age based on middle Pliocene nannofossils and foraminifers. 
Table 1 (continued).

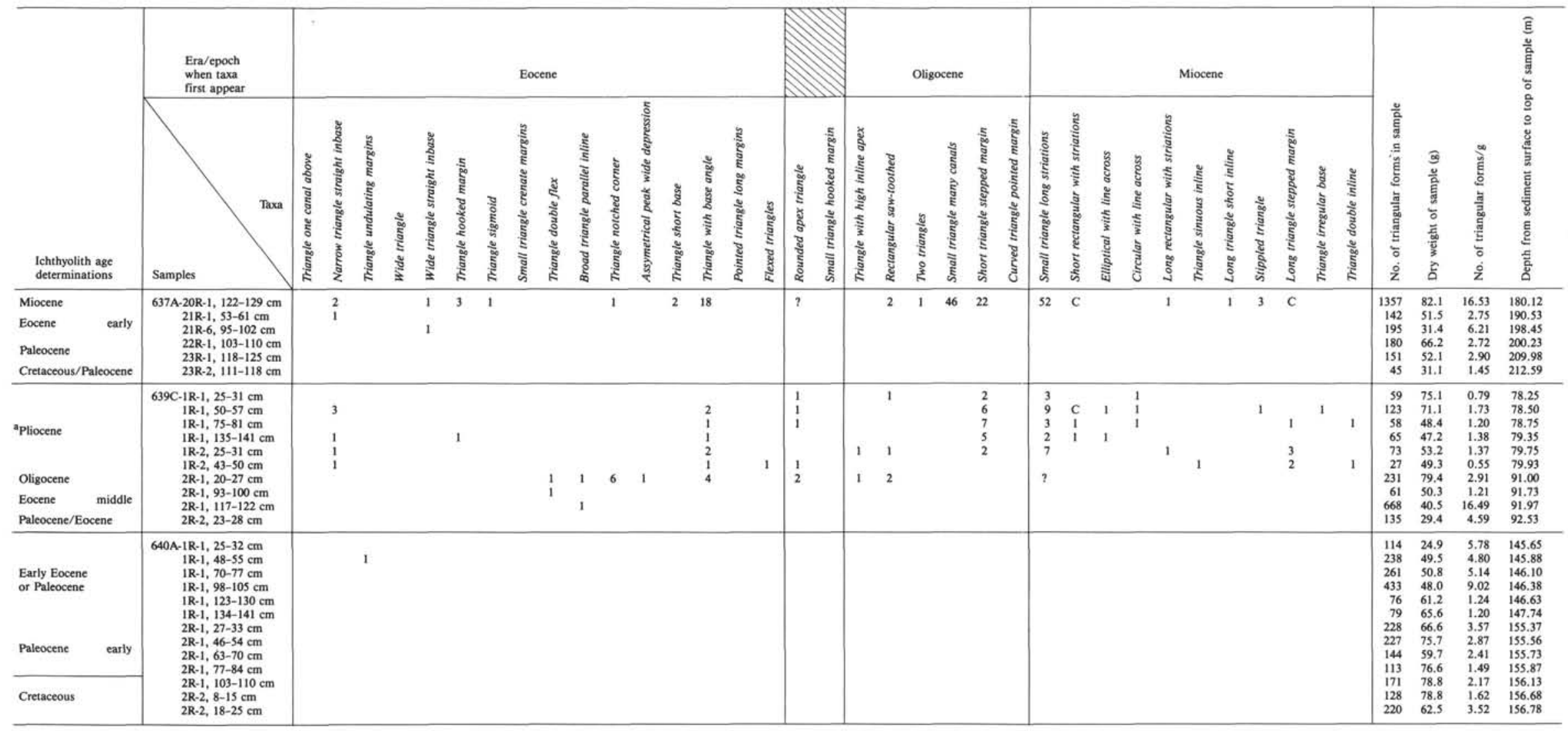


Table 2. Distribution of selected, stratigraphically useful taxa in samples with ages assigned on the bases of microfossils other than ichthyoliths. Samples from the three DSDP sites are collated by age to form a preliminary reference column for the Eastern Atlantic. Conventions are the same as for Table 1.

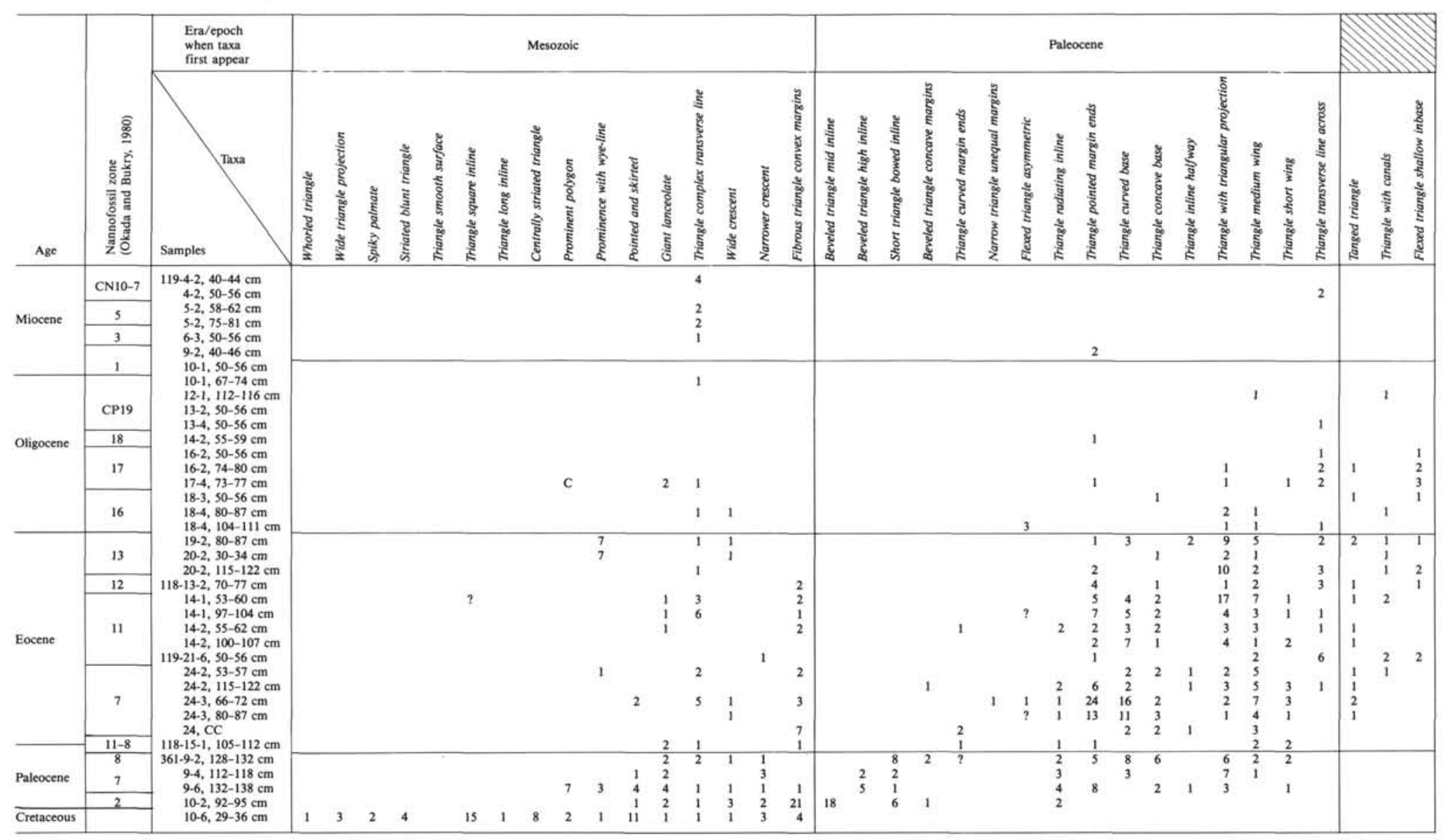

a DSDP samples $\left(50 \mathrm{~cm}^{3}\right.$ ) that have only bone fragments or are barren of ichthyolith are Samples $118-16-1,73-80 \mathrm{~cm}, 119-2-2,60-64 \mathrm{~cm}, 119-2-5,50-56 \mathrm{~cm}, 119-3-2,60-66 \mathrm{~cm}, 119-25-1,92-99$ 
Table 2 (continued).

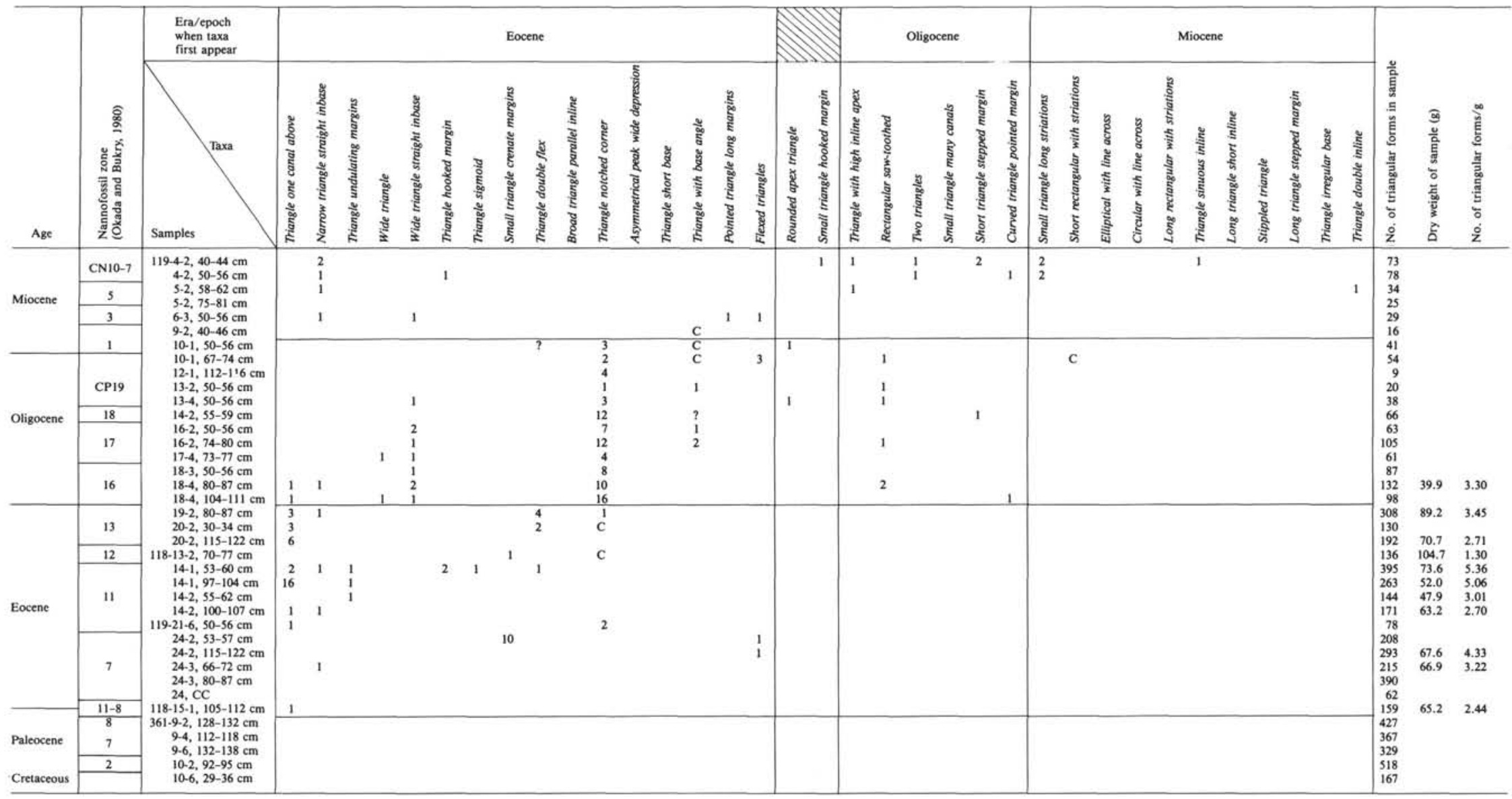


recovered in the South Pacific during DSDP Leg 91. It appears in many of the samples investigated here and ranges from the Cretaceous through the Tertiary, and possibly through Recent.

+ Broad triangle parallel inline Gottfried et al., 1984a.

+ Centrally striated triangle Doyle et al., 1978; emend. Winfrey et al., 1987.

+Circular with line across Doyle et al., 1974; Doyle and Riedel, 1985a, p. 973.

Crossed kite Winfrey et al., 1987. Described originally from South $\mathrm{Pa}-$ cific Mesozoic assemblages, the subtype appears in Cretaceous Samples 103-640A-2R-1, 103-110 cm (8 specimens), 103-640A-2R-2, 18$25 \mathrm{~cm}$ (3 specimens), and 361-10-6, 29-36 cm (7 specimens).

+ Curved triangle pointed margin Doyle et al., 1974; Doyle and Riedel, 1985 a, p. 978.

+Elliptical with line across Doyle et al., 1974; Doyle and Riedel, 1985a, p. 974.

+ Fibrous triangle convex margins Tway et al., 1985.

+ Flexed triangle asymmetric Doyle and Riedel, 1985b.

+ Flexed triangle shallow inbase Doyle et al., 1974.

+ Flexed triangles Doyle et al., 1974; Doyle and Riedel, 1985a, p. 976. The three described subtypes Flexed triangle 102-112, Flexed triangle 115-118, and Flexed narrow triangle 120-128 were differentiated by combinations of the characters describing the width of the apex and the margin flexure. The author's recent work with extant fish indicates that this combination of characters is unlikely to produce stratigraphically restricted taxa because one fish has a wide spectrum of flexure angles and teeth of various widths. These three taxa are grouped together in this study.

+Giant lanceolate Doyle et al., 1974; Doyle and Riedel, 1979a.

+ Long rectangular with striations Doyle et al., 1974; Doyle and Riedel, 1979a.

+ Long triangle short inline Gottfried et al., 1984a.

+ Long triangle stepped margin Doyle et al., 1974; Doyle and Riedel, 1985a, p. 987. The range of this taxon extends from the late Miocene to Recent. The specimen found in the Miocene Sample 103-637A$20 \mathrm{R}-1,122-129 \mathrm{~cm}$, differs in that the margins are smoother (less stepped) than specimens of this subtype.

Narrow curved triangle small top Ramsey et al., 1976; Doyle and Riedel, 1979a. Described originally from Aptian-Albian deposits in Italy, one specimen occurs in the lower Paleocene Sample 103-640A2R-1, 77-84 cm.

Narrow triangle sharply pointed Ramsey et al., 1976; Doyle and Riedel, 1979a. Originally described from Italian Jurassic deposits together with similar appearing forms with characteristic fibrous-like appearance (Triangle sigmoid rough and Triangle trailing margin), this subtype appears throughout intervals of Late Cretaceous and early $\mathrm{Pa}$ leocene age at Hole 361 and in the lower Paleocene Samples 103$640 \mathrm{~A}-2 \mathrm{R}-1,63-70 \mathrm{~cm}$, and $103-640 \mathrm{~A}-2 \mathrm{R}-1,77-84 \mathrm{~cm}$.

+ Narrow triangle straight inbase Doyle et al., 1974; Doyle and Riedel, 1979a.

+ Narrow triangle unequal margins Doyle and Riedel, 1985b.

+ Narrower crescent Doyle et al., 1978; Doyle and Riedel, 1979a.

+ Pointed and skirted Doyle et al., 1978; Doyle and Riedel, 1985a, p. 971.

+ Pointed triangle long margins Gottfried et al., 1984a.

Polygon with cross Winfrey et al., 1987. Initially described from Jurassic and Cretaceous DSDP Leg 91 assemblages, one specimen each occurs in the Cretaceous Samples 103-640A-2R-2, 18-25 cm, and $361-10-6,29-36 \mathrm{~cm}$, and the Paleocene Sample 361-9-2, 128-132 cm.

Polygon with skewed cross Winfrey et al., 1987. Described from the same material as Polygon with cross and similar to it morphologically, 9 specimens occur in Cretaceous Samples 361-10-6, 29$36 \mathrm{~cm}, 1$ specimen in Sample 103-640A-2R-2, 8-15 cm, and 5 specimens in Sample 103-640A-2R-2, 18-25 cm. One specimen occurs in the lower Paleocene Sample 103-640A-2R-1, 46-54 cm, possibly as a result of sediment mixing.

+Prominence with wye-line Doyle et al., 1978; Doyle and Riedel, 1985a, p. 970. The specimen in the lower Eocene Sample 103-637A-21R-1, 53-61 cm, does not have a median longitudinal line.

+ Prominent polygon Doyle et al., 1978; Doyle and Riedel, 1985a, p. 972. Although various forms similar to this Cretaceous subtype occur throughout the Cenozoic, the sides of the polygon are of unequal lengths (one of the main characters that distinguishes Prominent polygon from similar occurring forms is the equal lengths of the sides). The specimen in Oligocene Sample 119-17-4, 73-77 cm, closely approaches the regularity of the Cretaceous forms.
+Rectangular saw-toothed Doyle et al., 1974; Doyle and Riedel, 1985a, p. 974.

+ Rounded apex triangle Doyle et al., 1974; Doyle and Riedel, 1985a, p. 991.

Scalloped polygon Winfrey et al., 1987. Described initially from South Pacific Jurassic and Cretaceous samples collected during DSDP Leg 91, one specimen occurs in Paleocene Sample 103-640A-2R-1, 70$84 \mathrm{~cm}$.

+ Short rectangular with striations Doyle et al., 1974; Doyle and Riedel, 1979a. Forms occur that are similar to this subtype in every character but lack striations.

+ Short triangle bowed inline Doyle et al., 1978; Doyle and Riedel, 1979a. The specimen in Eocene Sample 103-637A-21R-1, 53-61 cm, is similar to the Paleocene forms, but its base is markedly concave and the outline narrower (Pl. 4, Fig. 15).

+ Short triangle stepped margin Doyle et al., 1974; Doyle and Riedel, 1985 a, p. 987.

Simple triangle Winfrey et al., 1987. Described from Jurassic-Cretaceous assemblages from the South Pacific, it is found in Samples $119-24-3,80-87 \mathrm{~cm}$ (1 specimen), 118-15-1, 105-112 cm (1), 103637A-23R-2, 111-118 cm (1), 361-10-2, 92-95 cm (1), and 361-10-6, 29-36 cm (1).

Small circular center Doyle et al., 1974. One specimen occurs in Pliocene Sample 103-640A-1R-1, 25-32 cm.

+ Small triangle crenate margins Dunsworth et al., 1975.

+ Small triangle long striations Dunsworth et al., 1975; Doyle and Riedel, 1985a, p. 983.

+ Small triangle many canals Tway et al., 1985.

+ Spiky palmate Doyle and Riedel, 1980; Doyle and Riedel, 1985a, p. 991.

+ Stippled triangle Dunsworth et al., 1975; Doyle and Riedel, 1985a, p. 990.

Straight triangle keeled edges Ramsey et al., 1976; Doyle and Riedel, 1979a. Originally described from Italian Upper Jurassic deposits, one specimen occurs in each of the Paleocene Samples 103-640A$1 \mathrm{R}-1,98-105 \mathrm{~cm}$, and 103-640A-2R-1, 46-54 cm.

+ Striated blunt triangle Doyle et al., 1978; Doyle and Riedel, 1985a, p. 984. A form occurs in Cretaceous samples in this region that is similar in some characters to both Centrally striated triangle and Striated blunt triangle. The three specimens illustrated in Plate 4, Figures $10-12$, are similar in outline to Centrally striated triangle (Pl. 4, Fig. 9), but the pattern of striations is more similar to Striated blunt triangle ( $\mathrm{Pl} .4$, Fig. 13).

+ Tanged triangle Gottfried et al., 1984a.

+ Triangle complex transverse line Doyle et al., 1974; Doyle and Riedel, 1979a.

+ Triangle concave base Dunsworth et al., 1975; Doyle and Riedel, 1979a.

+ Triangle curved base Doyle et al., 1978; Doyle and Riedel, 1985a, p. 981.

+ Triangle curved margin ends Doyle and Riedel, 1985b.

+ Triangle double flex Dunsworth et al., 1975; Doyle and Riedel, 1979a.

+ Triangle double inline Gottfried et al., 1984a.

+ Triangle hooked margin Doyle et al., 1974; Doyle and Riedel, 1985a, p. 978.

+ Triangle inline halfway Doyle et al., 1974; Doyle and Riedel, 1979a. + Triangle irregular base Gottfried et al., 1984a.

+ Triangle long inline Doyle et al., 1978; Doyle and Riedel, 1985a, p. 988. A co-occurring form in the Cretaceous samples from the Galicia margin is broader at the base and shorter (Pl. 4, Fig. 5-8) than this subtype, initially described from South Atlantic DSDP 361 assemblages.

+ Triangle medium wing Doyle et al., 1974; Doyle and Riedel, 1985a, p. 977.

Triangle modified margin ends Doyle and Riedel, 1985b. One specimen occurs in lower Paleocene Sample 103-640A-2R-1, 117-123 cm.

+ Triangle notched corner Doyle et al., 1974; Doyle and Riedel, 1985a, p. 983. Forms similar to Triangle notched corner are present in the DSDP Leg 119 sequence but have one or no notch at the base of the margins (Pl. 4, Fig. 4).

+ Triangle one canal above Doyle et al., 1974; Doyle and Riedel, 1979a.

+ Triangle pointed margin ends Doyle et al., 1974; Doyle and Riedel, $1985 a$, p. 980.

+ Triangle radiating inline Doyle and Riedel, 1985b. This form is recorded only from Paleocene and early Eocene age assemblages. The specimen in Cretaceous Sample 103-640A-2R-1, 103-110 cm, has dim 
striations extending from the inline and has a generally similar outline shape (Pl. 4, Fig. 14). Because the striated inline character has not been observed in Cretaceous specimens, it is likely that the specimen is displaced from the overlying Tertiary.

+ Triangle short base Tway et al., 1985.

+ Triangle short wing Doyle et al., 1974; Doyle and Riedel, 1985a, p. 977.

+ Triangle sigmoid Dunsworth et al., 1975; Doyle and Riedel, 1979a.

Triangle sigmoid rough Ramsey et al., 1976; Doyle and Riedel, 1979a. Eight specimens are present in Paleocene samples from DSDP Hole 361 and ODP Hole 640A.

+ Triangle sinuous inline Gottfried et al., 1984a.

+ Triangle smooth surface Doyle and Riedel, 1980; Doyle and Riedel, 1985 a, p. 989.

+ Triangle square inline Doyle et al., 1978; Doyle and Riedel, 1985a, p. 985 .

+ Triangle transverse line across Doyle et al., 1974; Doyle and Riedel, 1985 a, p. 980.

+ Triangle undulating margins Tway et al., 1985.

+ Triangle with base angle Dunsworth et al., 1975; Doyle and Riedel, $1985 a$, p. 982. Several variations in the characters used to describe this subtype from Northwest Pacific sediments occur in this relatively common form in the Galicia margin samples. The most frequent are specimens with both margins approximately the same length, rather than one margin markedly longer (Pl. 4, Fig. 1). In another form, the apex resembles Triangle with base angle, but the base is more similar to Triangle notched corner with margins of equal length and both sides of the base slightly notched or angled (Pl. 4, Fig. 3). Another form that resembles this group has margins modified by angles or curves in the middle third of the outline, not at the base (Pl. 4, Fig. 2).

+ Triangle with canals Doyle et al., 1974; Doyle and Riedel, 1979a.

+ Triangle with high inline apex Doyle et al., 1974; Doyle and Riedel, 1985 a, p. 979.

Triangle with humps Winfrey et al., 1987. Originally described from Mesozoic South Pacific assemblages, the subtype appears here in lower Paleogene Samples 118-15-1, 105-112 cm, and 103-637A-22R-1, $103-110 \mathrm{~cm}$, and in Cretaceous Sample 103-640A-2R-1, 103-110 cm.

+ Triangle with triangular projection Helms and Riedel, 1971, Fish tooth type B; Doyle and Riedel, 1985a, p. 986.

Triangular toothed Doyle et al., 1978. One specimen each occurs in Cretaceous-Paleocene Samples 103-640A-2R-1, 103-110 cm, and 103640A-2R-1, 77-84 cm.

+ Two triangles Doyle et al., 1974; Doyle and Riedel, 1985a, p. 974.

+ Whorled triangle Winfrey et al., 1987.

+Wide crescent Doyle et al., 1978; Doyle and Riedel, 1979a

+ Wide triangle Dunsworth et al., 1975; Doyle and Riedel, 1979a.

+Wide triangle projection Doyle et al., 1978; Doyle and Riedel, 1985a, p. 985 .

+ Wide triangle straight inbase Doyle et al., 1974; Doyle and Riedel, 1979a.

\section{CONCLUSIONS}

Ichthyoliths indicate that the brown clay intervals recovered at three sites during Leg 103 are of Cretaceous and Paleogene age, thus adding to the data accumulating on these relatively barren sediments in the Atlantic. At Site 637, a Miocene clay interval present in Section 103-637A-20R-1 contains ichthyoliths as well as foraminifers and nannofossils of late Miocene age. Because of spotty recovery, it is not clear whether a hiatus exists between the Miocene sediments and $25 \mathrm{~m}$ of Cretaceous through lower Eocene clay sediments (Cores 103-637A-21R through 103637A-23R) that overlie the basement. At Hole 639C, $1.9 \mathrm{~m}$ of Eocene to Oligocene brown clay was recovered in Core 103639C-2R. In Hole 640A, $3.5 \mathrm{~m}$ of Cretaceous through Paleocene clay unconformably overlie Aptian-Barremian chalk. A well-defined Cretaceous/Tertiary boundary is present in the second core in this hole, between Samples 103-640A-2R-1, 77$84 \mathrm{~cm}$, and $103-640 \mathrm{~A}-2 \mathrm{R}-1,103-110 \mathrm{~cm}$, although there is evidence of some mixing in the approximately $40 \mathrm{~cm}$ above the boundary. This corresponds with about the same extent of sediment mixing indicated by the iridium profile for the North Pacific from GPC-3 (Kyte and Watson, 1986).
Ichthyolith assemblages from Samples 103-640A-2R-1, 27$33 \mathrm{~cm}, 103-640 \mathrm{~A}-2 \mathrm{R}-1,46-54 \mathrm{~cm}, 103-640 \mathrm{~A}-2 \mathrm{R}-1,63-70 \mathrm{~cm}$, and $103-640 \mathrm{~A}-2 \mathrm{R}-1,77-84 \mathrm{~cm}$, in the $80 \mathrm{~cm}$ above the Cretaceous/ Tertiary boundary, are dominated by described and undescribed forms that were present during the Cretaceous. Several of these taxa (e.g., Triangle complex transverse line, Blunt triangle long margins, Large fibrous triangle, and Fibrous triangle convex margins) range through the Cenozoic to Recent and are not of use for Cenozoic age correlations.

\section{ACKNOWLEDGMENTS}

This work was supported by NSF Grant OCE84-19862 and NSF research support funds to E. L. Winterer from the U.S. Science Advisory Council through Texas A\&M University. W. R. Riedel and L. E. Tway provided thought-provoking discussion. M. S. Doyle patiently helped with the data entry and proofreading. A special thank you to Audrey W. Meyer, Michel Moullade, Andrew Gombos, and William Riedel, whose suggestions substantially improved the paper.

\section{REFERENCES}

Corliss, B. H., Hollister, C. D., et al., 1982. A paleoenvironmental model of Cenozoic sedimentation in the central North Pacific. In Scrutton, R. A., and Talwani, M. (Eds.), The Ocean Floor: New York (Wiley), 277-304.

Doyle, P. S., 1982. Subseabed disposal program: ichthyolith correlation of North Pacific cores. In Hinga, K. R. (Ed.), Subseabed Disposal Program Annual Report: Albuquerque (Sandia National Laboratories).

Doyle, P. S., Dunsworth, M. J., and Riedel, W. R., 1978. Ichthyoliths from some southeast Atlantic sediments, DSDP Leg 40. In Bolli, H. M., Ryan, W.B.F., et al., Init. Repts. DSDP, 40: Washington (U.S. Govt. Printing Office), 743-759.

Doyle, P. S., Kennedy, G. G., and Riedel, W. R., 1974. Stratignathy. In Davis, T. A., Luyendyk, B. P., et al., Init. Repts. DSDP, 26: Washington (U.S. Govt. Printing Office), 825-905.

Doyle, P. S., and Riedel, W. R., 1979a. Ichthyoliths: present status of taxonomy and stratigraphy of microscopic fish skeletal debris. Ref. Ser. Scripps Inst. Oceanogr., 75-16.

1979b. Cretaceous to Neogene ichthyoliths in a giant piston core from the central North Pacific. Micropaleontology, 25:337-364. 1980. Ichthyoliths from Site 436, Northeast Pacific, Leg 56, Deep Sea Drilling Project. In Scientific Party, Init. Repts. DSDP, 56, 57, Pt. 2: Washington (U.S. Govt. Printing Office), 887-893.

1985a. Cenozoic and Late Cretaceous ichthyoliths. In Bolli, H. M., Saunders, J. B., and Perch-Nielsen, K. (Eds.), Plankton Stratigraphy: Cambridge (Cambridge Univ. Press), 965-995.

1985b. Ichthyolith biostratigraphy of western North Pacific clays, DSDP 86. In Heath, G. R., Burkle, L. H., et al., Init. Repts. $D S D P, 86$ : Washington (U.S. Govt. Printing Office), 349-366.

Dunsworth, M. J., Doyle, P. S., and Riedel, W. R., 1975. Ichthyoliths from some northwest Pacific sediments, DSDP Leg 32. In Larson, R. L., Moberly, R., et al., Init. Repts. DSDP, 32: Washington (U.S. Govt. Printing Office), 853-863.

Edgerton, C. C., Doyle, P. S., and Riedel, W. R., 1977. Ichthyolith age determinations of otherwise unfossiliferous Deep Sea Drilling Project cores. Micropaleontology, 23:194-205.

Gottfried, M. D., Doyle, P. S., and Riedel, W. R., 1984a. Advances in ichthyolith stratigraphy of the Pacific Neogene and Oligocene. Micropaleontology, 30:71-85.

1984b. Stratigraphic interpretations of pelagic sequences revised on the basis of ichthyoliths. Micropaleontology, 30:426-444.

Helms, P. B., and Riedel, W. R., 1971. Skeletal debris of fishes. In Winterer, E. L., Riedel, W. R., et al., Init. Repts. DSDP, 7, Pt. 2: Washington (U.S. Govt. Printing Office), 1709-1720.

Kaneps, A. G., Doyle, P. S., and Riedel, W. R., 1981. Further ichthyolith age determinations of otherwise unfossiliferous Deep Sea Drilling Project cores. Micropaleontology, 27:317-331.

Kyte, F. T., and Watson, J. T., 1986. Accretion rate of extraterrestrial matter: iridium deposited 33 to 67 million years ago. Science, 232: $1225-1229$.

Okada, H., and Bukry, D., 1980. Supplementary modification and introduction of code numbers to the low-latitude coccolith biostratigraphic zonation (Bukry, 1973; 1975). Mar. Micropaleontol., 5:321325 . 
Ramsey, C. A., Doyle, P. S., and Riedel, W. R., 1976. Ichthyoliths in Late Mesozoic pelagic sediments, mainly from Italy. Micropaleontology, 22:181-198.

Shipboard Scientific Party, 1987. Site 637. In Boillot, G., Winterer, E. L., et al., Proc. ODP, Init. Repts., 103: College Station, TX (Ocean Drilling Program), 123-219.

Tway, L. E., Doyle, P. S., and Riedel, W. R., 1985. Correlation of dated and undated Pacific samples based on ichthyoliths and clustering techniques. Micropaleontology, 31:295-319.
Winfrey, E. C., Doyle, P. S., and Riedel, W. R., 1987. Preliminary ichthyolith biostratigraphy, southwest Pacific, DSDP Leg 91. In Menard, H. W., Natland, J. H., Init. Repts. DSDP, 91: Washington (U.S. Govt. Printing Office), 447-468.

Date of initial receipt: 22 January 1987

Date of acceptance: 14 July 1987

Ms 103B-153 


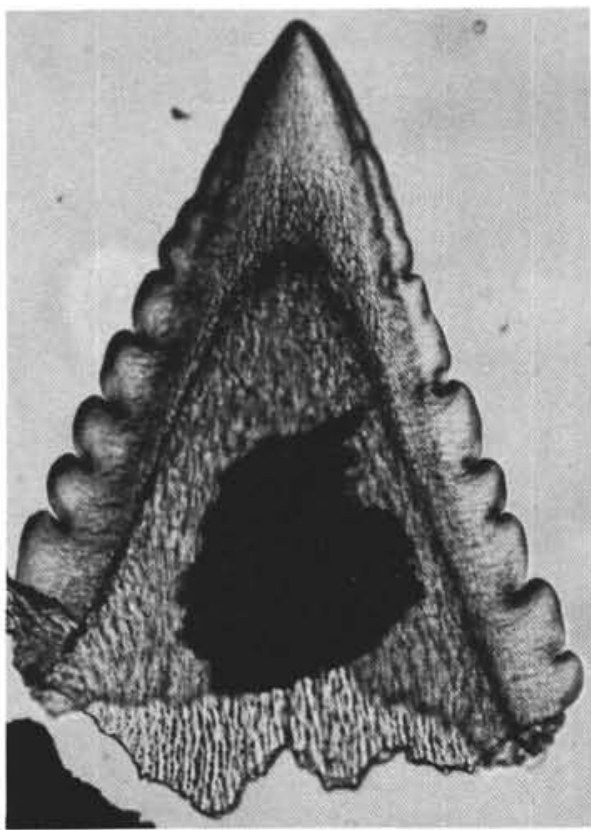

1

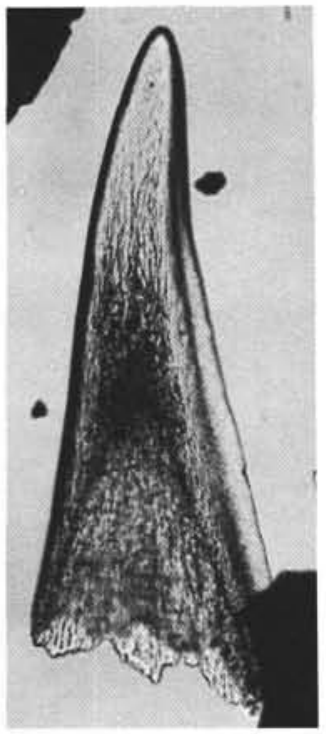

4

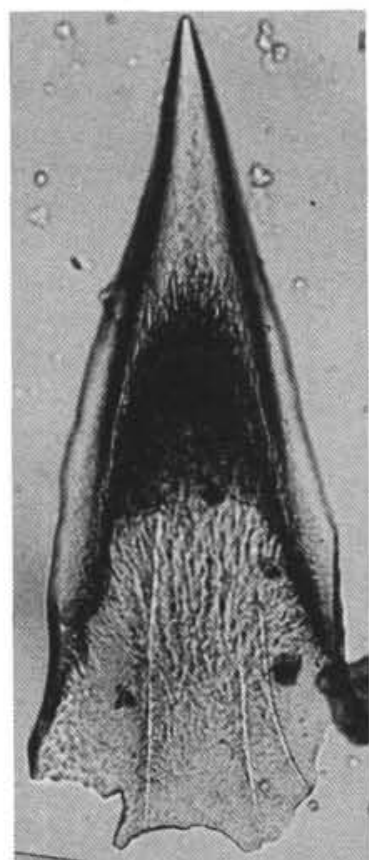

2

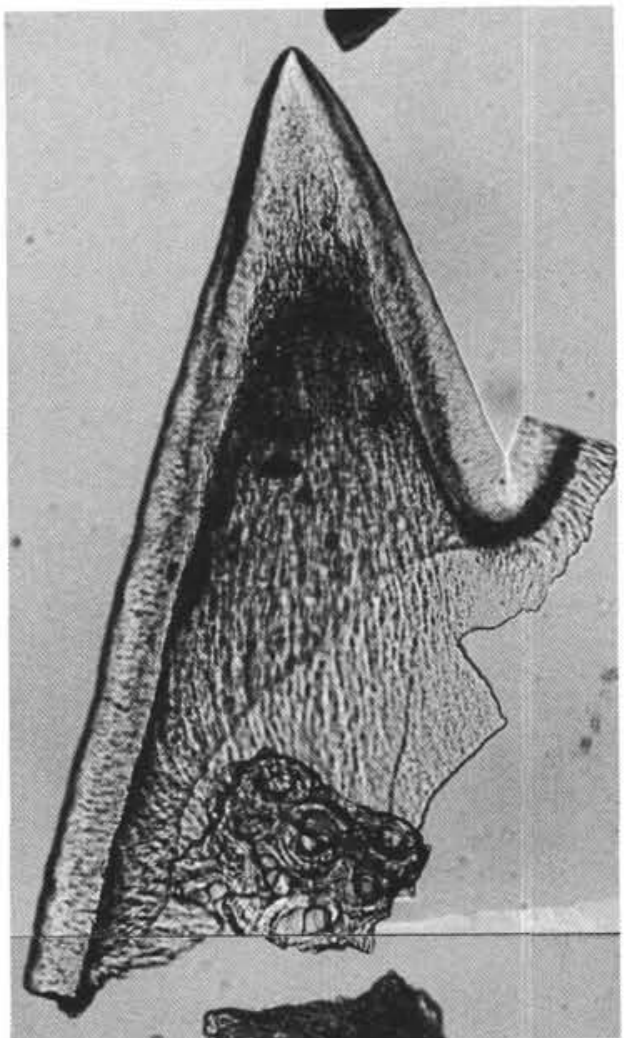

3

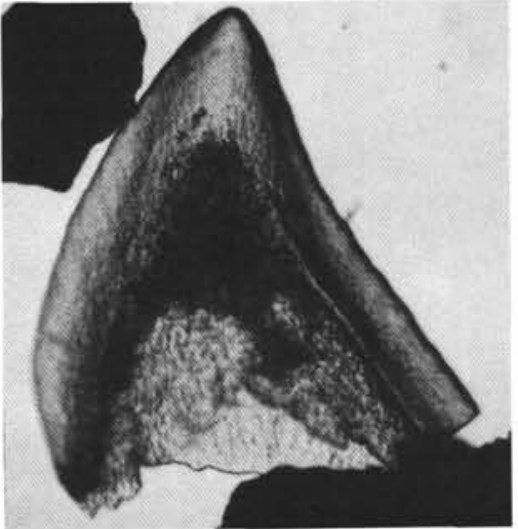

6

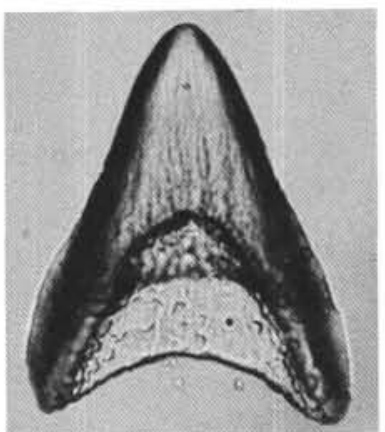

7

Plate 1. Mesozoic ichthyoliths that continue into the Cenozoic. In the figure explanations, numbers/letters following the sample designation give the slide location of the specimen in the Scripps Institution of Oceanography collection. Magnifications between $67 \times$ and $163 \times$, as noted. 1. Unusual, fibrous-type tooth with serrated edges. Undescribed. Paleocene Sample 103-640A-2R-1, $46-54 \mathrm{~cm} ; 149-1$, V36. 106 $\times$. 2. Undescribed, fibrous-type teeth with keeled edges. Lower Eocene Sample 119-24-3, 80-87 cm; 149-1, S38. 163×. 3. Form similar to Fibrous triangle convex margins Tway et al. (1985) and Curved fibrous triangle Tway et al. (1985), but with straight margins. Paleocene Sample 103-640A-2R-1, 46-54 cm; 149-1, D36. $106 \times$. 4. Large fibrous triangle Tway et al. (1985). Paleocene Sample 103-640A-2R-1, 46-54 cm; 149-1, H19. 106× . 5. Undescribed, fibrous-type teeth with keeled edges. Paleocene Sample 361-9-2, 128-132 cm; s1.12, K44. 106 .6 . 6. Undescribed, fibrous-type teeth with keeled edges. Paleocene Sample 103-640A-2R-1, 63-70 cm; 149-1, X19.67 ×. 7. Nonfibrous tooth similar to Simple triangle Winfrey et al. (1987) but with curved margins and more extensive inline. Paleocene Sample 103-640A-2R-1, 63-70 cm; 149-1, H28. 163×. 


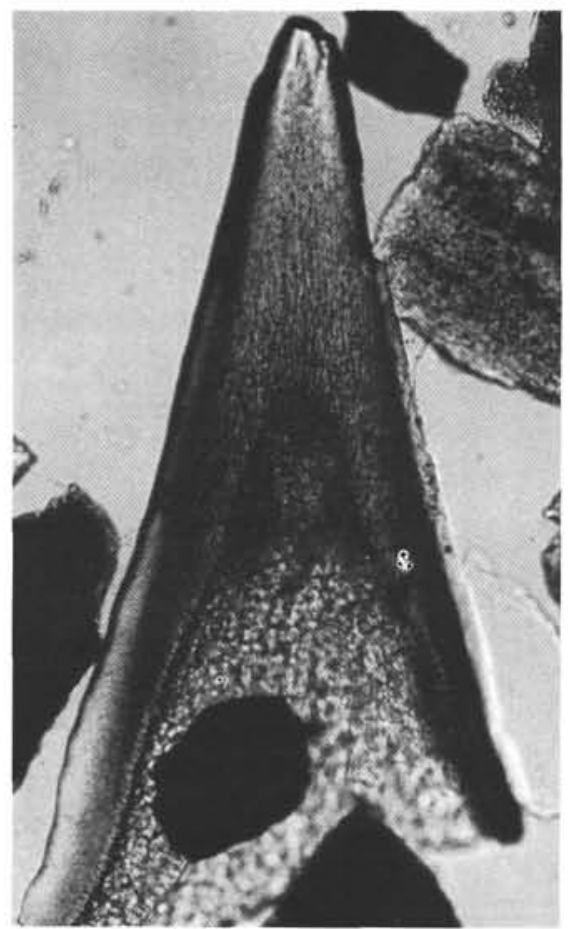

1

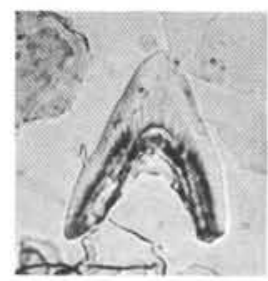

5

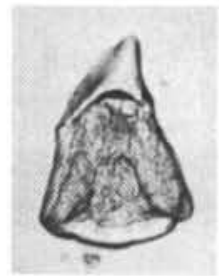

10

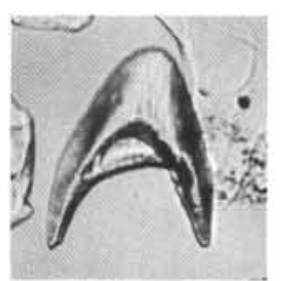

6

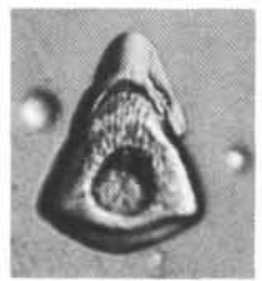

11

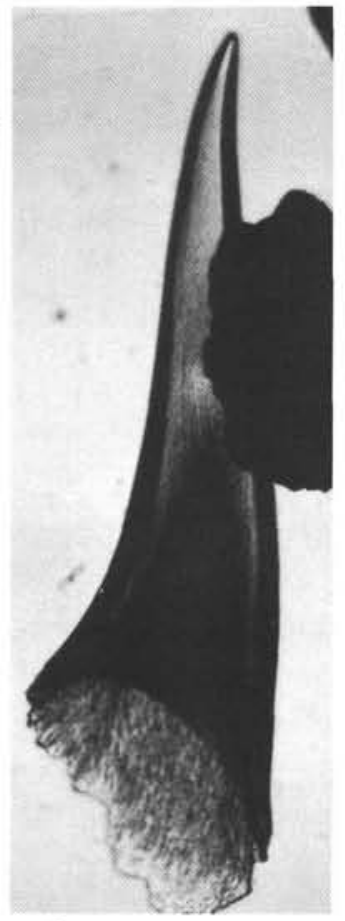

2

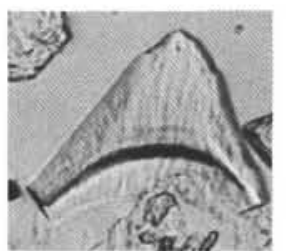

7

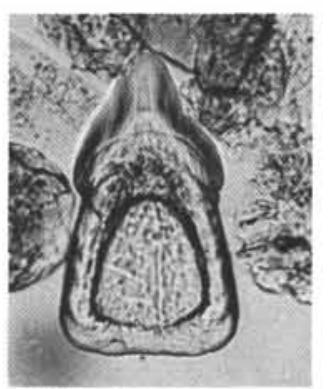

12

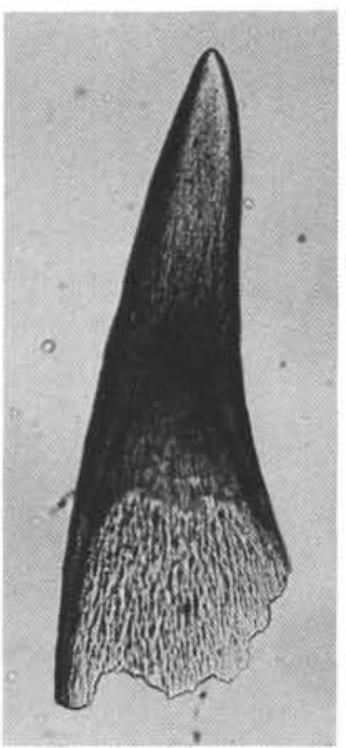

3

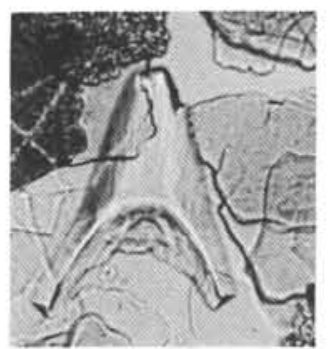

8

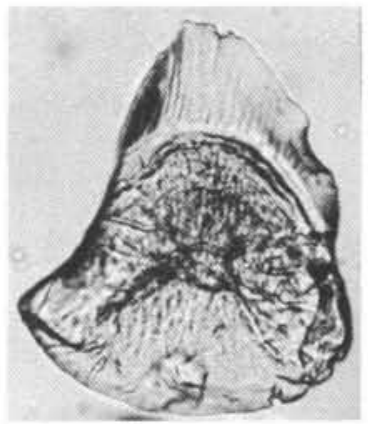

13

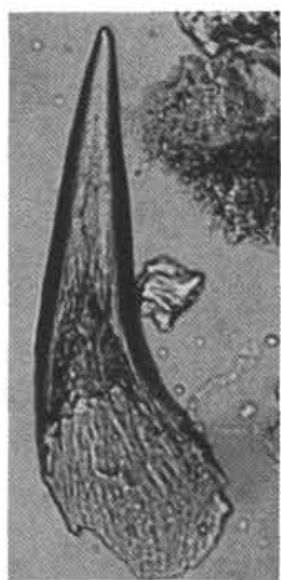

4

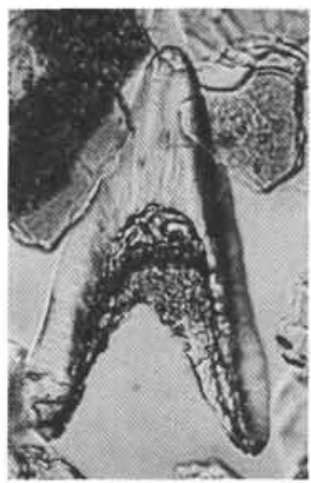

9

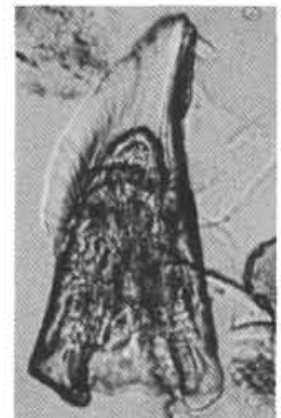

14

Plate 2. Mesozoic ichthyoliths that continue into the Cenozoic. In the figure explanations, numbers/letters following the sample designations give the slide location of the specimen in the Scripps Institution of Oceanography collection. Samples are early Paleocene age and magnifications are $163 \times$, unless otherwise noted. 1. Undescribed, fibrous-type tooth. Sample 103-640A-2R-1, 46-54 cm; 149-1, J29. 106 $\times$. 2. Triangle sigmoid rough Ramsey et al. (1976). Sample 103-640A-2R-1, 63-70 cm; 149-1. 67×. 3. Large fibrous triangle Tway et al. (1985). Sample 103-640A-2R-1, 46$54 \mathrm{~cm}$; 149-1, H19. 106×. 4. Similar to Triangle trailing margin Ramsey et al. (1976). Sample 103-640A-2R-1, 77-84 cm; 63-1, W18. 5. Undescribed. Sample 103-640A-2R-1, 46-54 cm; 63-2, E37. 6. Undescribed. Sample 103-640A-2R-1, $46-54 \mathrm{~cm} ; 63-1$, O31. 7. Undescribed. Sample 103-640A-2R-1, 46-54 cm; 63-3, T43. 8. Similar to Simple triangle Winfrey et al. (1987) but with more extensive inline. Sample 103-640A-2R-1, 46$54 \mathrm{~cm} ; 63-2$, J23. 9. Similar to Wide triangle keeled edges Ramsey et al. (1976) but narrower. Sample 103-640A-2-1, 46-54 cm; 63-3, H44. 10. Undescribed form similar to Capped triangle Ramsey et al. (1976). Eocene Sample 118-14-1, 53-60 cm; 63-1, R42. 11. Undescribed form similar to Capped triangle Ramsey et al. (1976). Cretaceous Sample 103-640A-2-2, 18-25 cm; 63-1, Z16. 12. Triangle with humps Winfrey et al. (1975). Cretaceous Sample 103-640A-2-1, 103-110 cm; 63-6, S13. 13. Undescribed. Cretaceous Sample 103-640A-2R-1, 103-110 cm; 149-1, V35. 14. Similar to Pointed triangle arcuate inline Winfrey et al. (1987) but curved. Sample 103-640A-2R-1, 46-54 cm; 63-5, J27. 


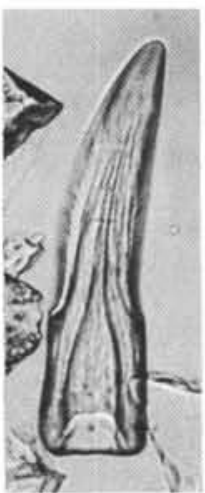

1

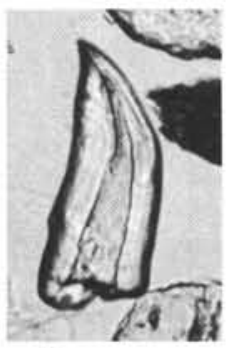

3

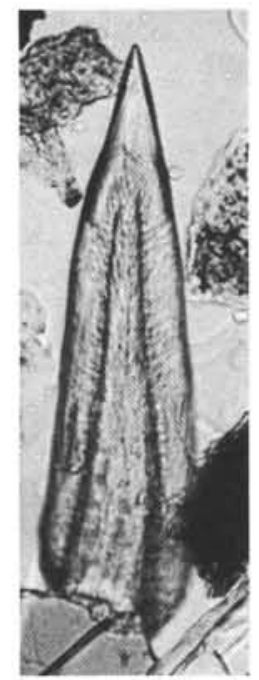

16

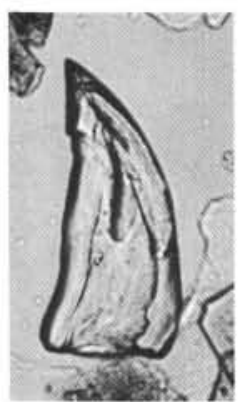

2

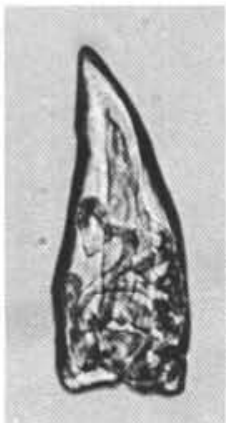

4

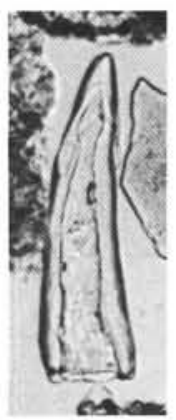

5

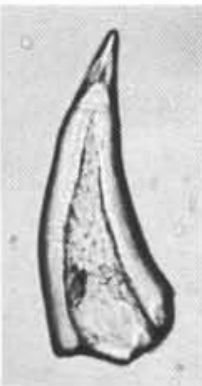

6

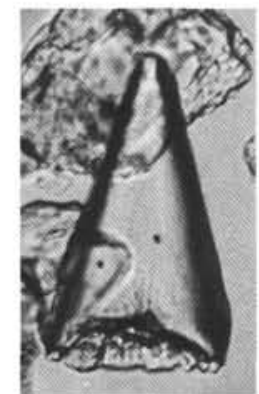

10

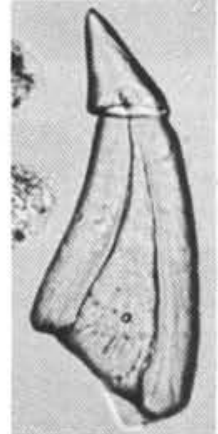

7

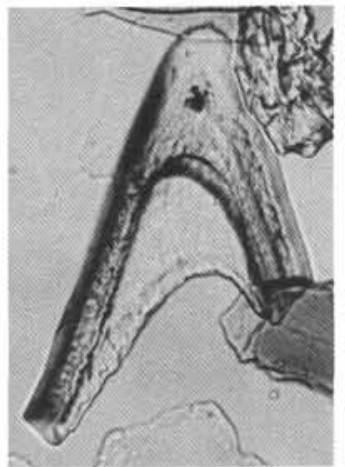

11

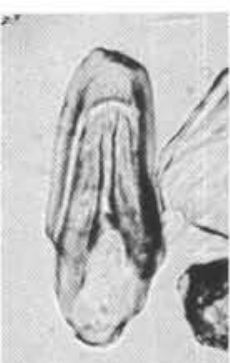

8

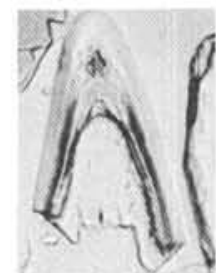

12

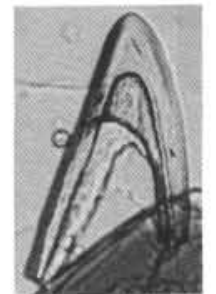

14

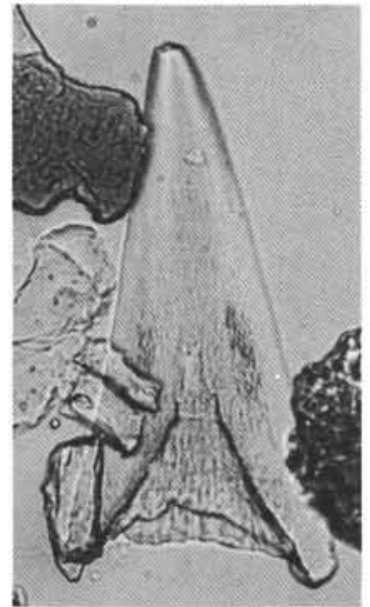

18

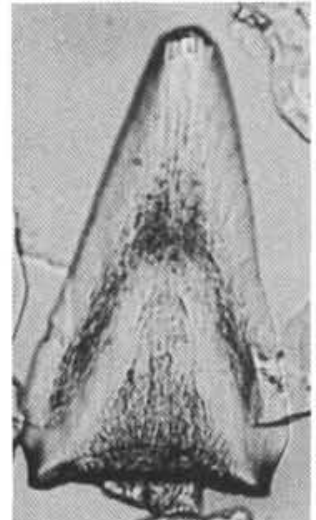

19
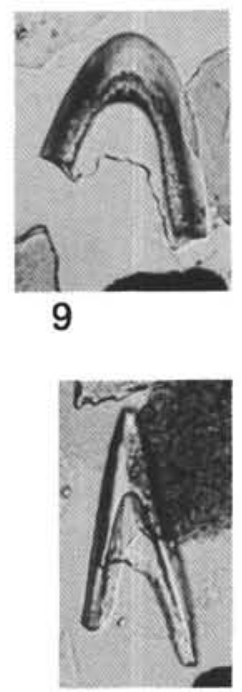

13

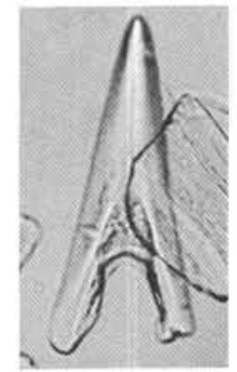

15

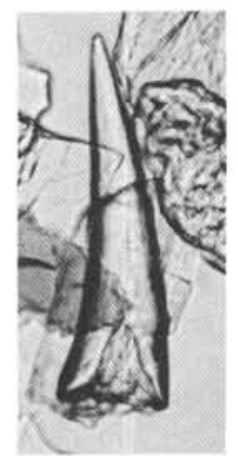

20

Plate 3. Mesozoic ichthyoliths that continue into the Cenozoic. In the figure explanations, numbers/letters following the sample designation give the slide location of the specimen in the Scripps Institution of Oceanography collection. The samples are Paleocene in age. Magnification is $163 \times$. 1. Triangle complex transverse line Doyle et al. (1974). Sample 103-640A-2R-2, 18-25 cm;63-1, V17. 2. Triangle complex transverse line Doyle et al. (1974). Sample 103-640A-2R-1, 46-54 cm; 63-2, L41. 3. Triangle complex transverse line Doyle et al. (1974). Sample 103-640A-2R-1, 77-84 cm; 63-1, F46. 4. Triangle complex transverse line Doyle et al. (1974). Sample 103-640A-2R-1, 77-84 cm; 63-1, F42. 5. Undescribed. Sample 103640A-2R-1, 77-84 cm; 63-1, C15. 6. Undescribed. Sample 103-640A-2R-1, 77-84 cm; 63-3, L17. 7. Undescribed. Sample 103-640A-2R-1, 77-84 cm; 63-2, C29. 8. Narrower crescent Doyle et al. (1978). Sample 103-640A-2R-1, 77-84 cm; 63-2, K37. 9. Narrower crescent Doyle et al. (1978). Sample 103-640A-2R-1, 63-70 cm; 63-3, J14. 10. Undescribed form illustrated by Winfrey et al. (1987; pl. 6, fig. 7) from a Mesozoic South Pacific assemblage. Sample 103-640A-2R-1, 77-84 cm; 63-2, M41. 11. Form similar to Blunt triangle long margins Winfrey et al. (1987) but with ends of the margins broken. Sample 103-640A-2R-1, 46-54 cm; 63-5, J47. 12. Form similar to Blunt triangle long margins Winfrey et al. (1987) but with ends of the margins broken. Sample 103-640A-2R-1, 46-54 cm; 63-3, O17. 13. Form similar to Blunt triangle long margins Winfrey et al. (1987) but with ends of the margins broken. Sample 103-640A-2R-1, 46-54 cm; 63-2, G19. 14. Form similar to Blunt triangle long margins Winfrey et al. (1987) but with ends of the margins broken. Sample 103-640A-2R-1, 46-54 cm; 63-3, K16. 15. Undescribed. Sample 103-640A-2R-1, 46-54 cm; 63-1, T31. 16. Undescribed. Sample 103-640A-2R-1, 77-84 cm; 63-2, E20. 17. Undescribed. Sample 103-640A-1R-1, 27-33 cm; 63-4, S22. 18. Undescribed. Sample 103-640A-2R-1, 46-54 cm; 63-3, J11. 19. Undescribed. Sample 103-640A-2R-1, 77-84 cm; 63-2, O37. 20. Undescribed. Sample 103-640A-2R-1, 46-54 cm; 63-3, K12. 

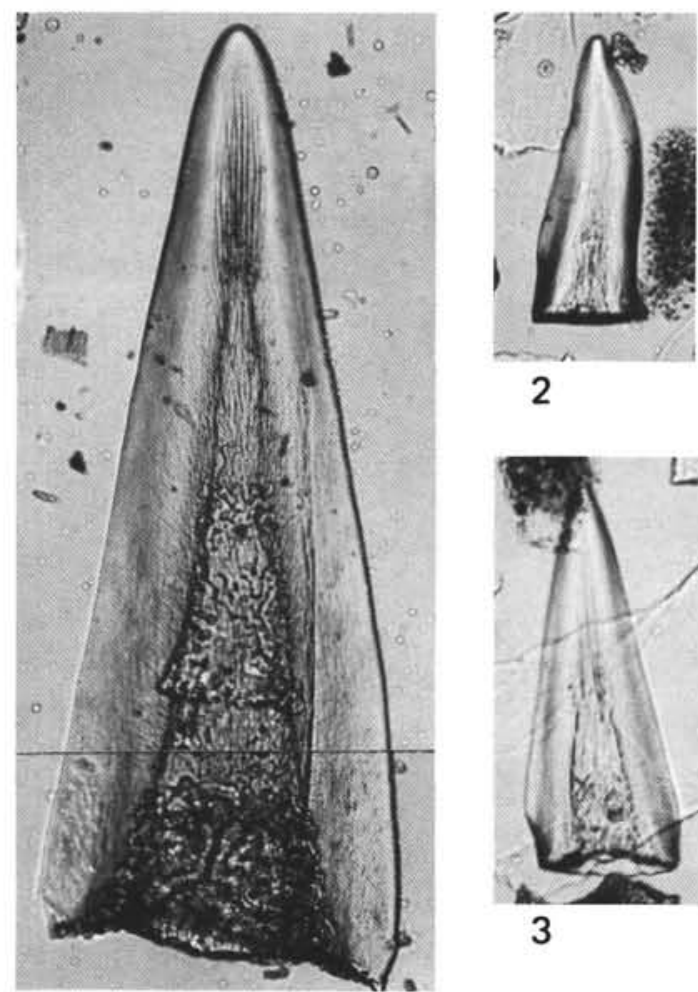

2

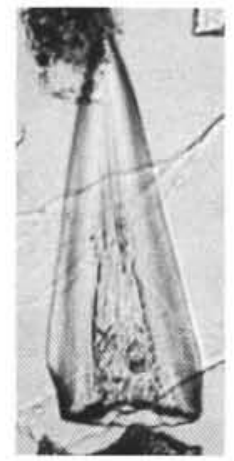

3

1

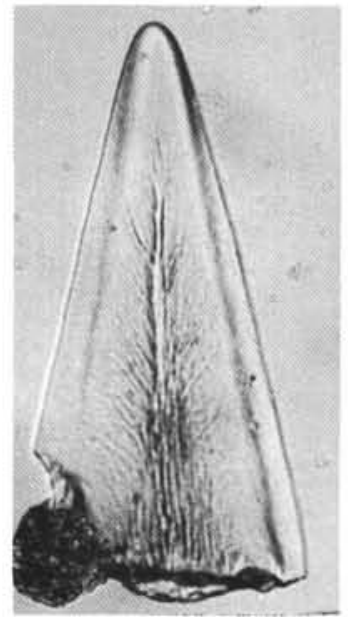

9

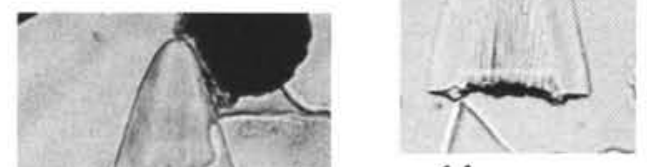

11

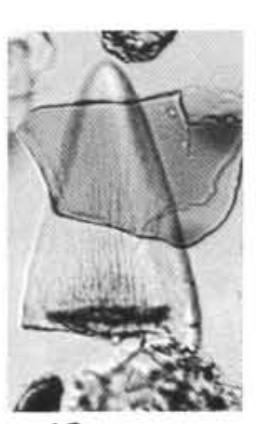

12

10

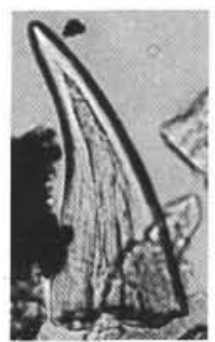

5
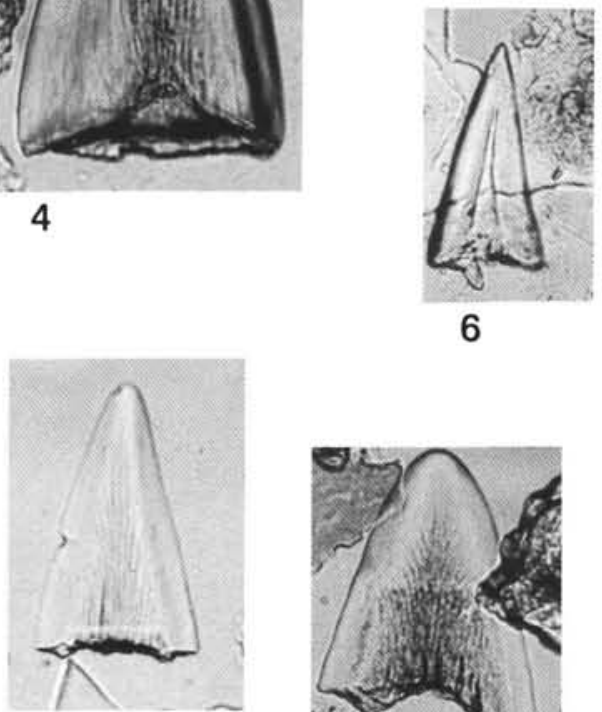

6

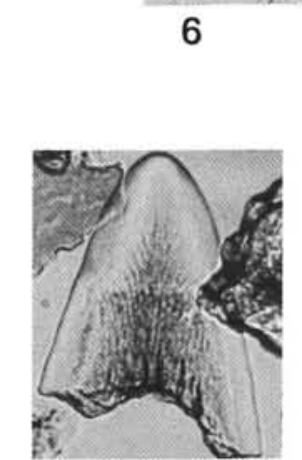

13

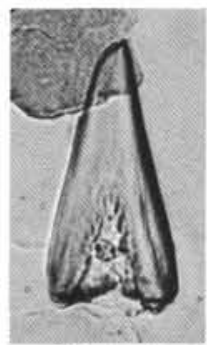

14

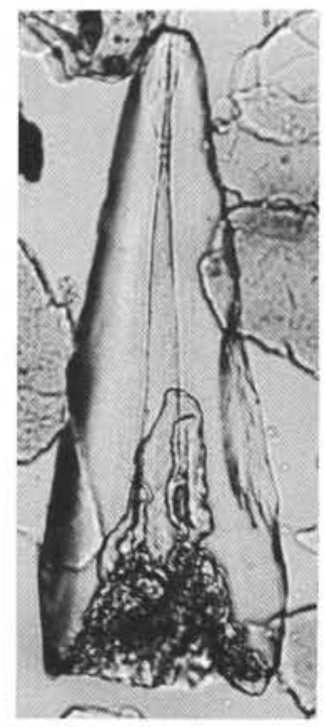

7

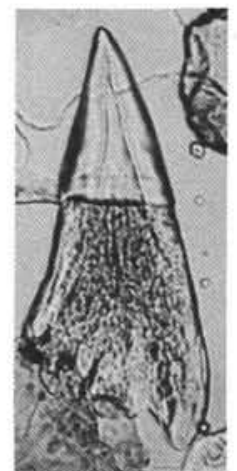

8

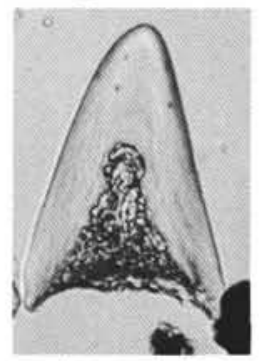

15

Plate 4. Ichthyoliths discussed in "List of Taxa" that are similar to the described subtypes but vary in one or more characters. In the figure explanations, numbers/letters following the sample designation give the location of the specimen in the Scripps Institution of Oceanography collection. Magnification $163 \times$, unless otherwise noted. 1. Unusually large specimen similar to Triangle with base angle Dunsworth et al. (1975) but narrower and with both margins similar in length. Sample 103-639C-1-2R, 25-31 cm; 149-1, 106 . 2. Undescribed specimen similar to Triangle with base angle. Sample 119-19-2, 80-87 cm; 63-3, Q29. 3. Undescribed specimen similar to Triangle with base angle. Sample 103-637A-20R-1, 122-129 cm; 63-5, V14. 4. Undescribed specimen similar to Triangle notched corner Doyle et al. (1974). Sample 119-13-4, 50-56 cm; s1.1, J10. 5. Undescribed specimen similar to Triangle long inline Doyle et al. (1978). Sample 103-640A-2R-2, 8-15 cm; 63-3, D28. 6. Undescribed specimen similar to Triangle long inline Doyle et al. (1978). Sample 103-640A-2R-2, 8-15 cm; 63-7, L22. 7. Undescribed specimen similar to Triangle long inline Doyle et al. (1978). Sample 103-640A-2R-1, 103-110 $\mathrm{cm}$; 63-4, M17. 8. Undescribed specimen similar to Triangle long inline Doyle et al. (1978). Sample 103-640A-2R-1, 103-110 cm; 63-7, E23. 9. Centrally striated triangle Doyle et al. (1978). Sample 103-640A-2R-2, 8-15 cm; 63-6, N39. 10. Undescribed form similar to Striated blunt triangle and Centrally striated triangle. Sample 103-640A-2R-2, 18-25 cm; 63-1, J35. 11. Undescribed form similar to Striated blunt triangle and Centrally striated triangle. Sample 103-640A-2R-2, 18-25 cm; 63-3, P46. 12. Undescribed form similar to Striated blunt triangle and Centrally striated triangle. Sample 103-640A-2R-1, 103-110 cm; 63-6, B11. 13. Striated blunt triangle Doyle et al. (1978). Sample 103-640A-2R-2, 18-25 cm; 63-1, W16. 14. Specimen similar to Triangle radiating inline Doyle et al. (1978). From a Cretaceous assemblage. Sample 103-640A-2R-1, 103-110 cm; 63-3, N34. 15. Form similar to Short triangle bowed inline Doyle et al. (1978). Sample 103-637A-21R-1, 53-61 cm; 63-3, H15. 